\title{
KM GOVERNANCE: THE MECHANISMS FOR GUIDING AND CONTROLLING KM PROGRAMS
}

\begin{abstract}
Purpose: To establish and sustain their KM programs organizations need to establish mechanisms to ensure their governance. KM programs require business integration, senior management involvement and decision making authority. The present research investigates the KM governance mechanisms organizations use to guide and control their KM programs. The research seeks to contribute to a better understanding of the governance of KM and to support organizations in the development of their KM programs.
\end{abstract}

Methodology: The study employs multiple case research methodology to analyze the KM governance arrangements of twelve international organizations and identify patterns in their governance configurations.

Findings: The analysis identifies a range of structural, process and relational mechanisms that are critical for governing an organizational KM program. Different patterns among the KM governance mechanisms are identified which lead to the development of generic KM governance typologies.

Research implications: The development of the KM governance framework allows future research to systematically investigate the KM governance phenomenon. As the present study is based on a configurational analysis future research should particularly target the performance implications of different KM governance configurations.

Practical implications: The research provides insights into the diversity of KM governance mechanisms and their impact on a KM program. The KM governance framework can assist 
managers in reviewing their present and prospective $\mathrm{KM}$ programs and thereby support benchmarking or re-organization efforts.

Originality: Building on prior research that has focused on individual KM governance aspects, the present study adopts a comprehensive perspective integrating structural, process and relational governance mechanisms.

Keywords: KM Governance, KM Function, Knowledge Management, IT Governance

Paper type: Research paper 


\section{INTRODUCTION}

The importance of knowledge for organizational success has been widely recognized (Davenport and Prusak, 1998; Drucker, 1993; Liebeskind, 1996; Nonaka, 1994). Dedicated knowledge management $(\mathrm{KM})$ programs have been established to systematically facilitate the creation and sharing of knowledge resources (Holden, 2004). Despite the organizational efforts many of these KM programs fail (Chua and Lam, 2005; Mason and Pauleen, 2003) and disillusionment about the possibility of managing knowledge resources has been voiced (Galliers and Newell, 2003). Failure of KM programs is often attributed to a lack of business integration and alignment, lack

of clear strategic objectives, lack of senior management supervision and unclear distribution of KM related authority (Alazmi and Zairi, 2003; Call, 2005; Chua and Lam, 2005; Plessis, 2007; Riege, 2005; Storey and Barnett, 2000; Suresh and Mahesh, 2006; Wong, 2005).

To address these administration and control issues an investigation of the governance of KM programs is required. Governance mechanisms, the organizational structures and processes, are critical for the development and success of an organizational initiative (Ein-Dor and Segev, 1978). They constitute the decision making and control environment which drives the development of an organizational initiative. Analyzing the governance mechanisms employed in the KM context would help to systematically advance research on organizational KM programs. A better understanding of KM governance may help researchers to investigate the underlying reasons for success and failure of $\mathrm{KM}$ programs and help decision makers to improve existing programs.

The present research draws on a contingency theoretical approach to organizational design (Lawrence and Lorsch, 1967) to guide the investigation of the governance arrangements of organizational KM programs. Governance mechanisms are viewed as structures, processes or relational mechanisms that help to integrate but also differentiate the KM program in the organization. Specifically, the research investigates the KM governance arrangements of 12 international organizations to identify (1) the mechanisms used to govern KM programs; (2) the relationships between organizational characteristics and KM governance configurations; (3) the 
relationships between the KM approach followed by organizations and KM governance configurations.

Based on the analysis a KM governance framework is developed which captures the diversity of emerging KM governance configurations. Different KM governance typologies are established to allow future research to systematically compare and contrast the control and decisions making environments of $\mathrm{KM}$ programs. By integrating established governance theory into the KM domain the research seeks to provide a well-grounded basis for future theoretical and practical investigation of the governance of KM programs.

The remainder of the paper is structured as follows: First, the pertinent research on knowledge management and governance is integrated to conceptualize the governance phenomenon in a KM context, which is presented in the form of propositions. Second, the case organizations are analyzed, the KM governance framework is developed and its relationships are identified. Finally, the research findings are discussed and concluding comments outlining limitations of the study and suggestions for further research are provided.

\section{CONCEPTUALIZING KM AND ITS GOVERNANCE}

This study follows Wiig's definition of KM as "the systematic, explicit, and deliberate building, renewal, and application of knowledge to maximize an enterprise's knowledge-related effectiveness and returns from its knowledge assets" (2000, p.6). Hence, a KM program describes a series of explicit technical or organizational initiatives which systematically address and support the various knowledge processes in an organization (Coakes, 2002).

'Governance', in an organizational context, describes the distribution of decision making rights and responsibilities and the procedures and mechanisms for making and monitoring strategic decisions (Peterson, 2004a). Governance configurations are designed to allocate accountability, facilitate interaction and create alignment. Lawrence and Lorsch (1967) viewed organizational design as an effort to selectively differentiate and integrate individual parts of the organization. Differentiation describes the segmentation of the organizational system into subsystems. 
Governance structures and processes define and create subsystems, for example by decentralizing a business function or providing local autonomy in the choice of operating procedures. Integration describes the process of achieving unity of effort among the various subsystems of which an organization is composed. Governance structures and processes are devised to ensure the common direction of the distributed effort, for example by centralizing decision making rights and introducing monitoring procedures.

Lawrence and Lorsch (1967) explain the differentiation and integration developments from a contingency theoretical perspective: the extent to which differentiation and integration mechanisms are established is dependent on the organizational context. The main premise of a contingency theoretical approach to organizational design is that there is no single best way of organizing a firm (Galbraith, 1973) and that different contingency factors create particular structural and procedural configurations (Donaldson, 2001; Mathiassen and Sørensen, 2008).

Governance in the KM context captures the mechanisms that differentiate and integrate knowledge related efforts within an organization. Focusing on the differentiation and integration efforts we define KM governance as the structures, processes and relational mechanisms established to steer, coordinate and control explicit and deliberate knowledge management initiatives in an organization. Particular KM governance arrangements that have been investigated include the centralization/decentralization of the KM function (Desouza and Awazu, 2006; Grolik et al., 2003), methods for integrating senior executives into decision making (Akhavan et al., 2006; Chua and Lam, 2005) and strategy development (Kannabiran and Pandyan, 2010; Maier, 2007; Smith and McKeen, 2003). A further range of KM governance arrangements are highlighted by Schroeder, Pauleen and Huff (2007; 2009). Zyngier, Burstein and McKay $(2005 ; 2004,2005$, 2006) have developed a KM governance framework focusing on the development and implementation of KM strategy.

As KM governance research is still in an early stage the present study draws on findings from the IT domain to conceptualize the governance phenomenon. Although KM and IT programs differ in the focus of their activities drawing on IT governance research is justified as both functions share the role of support functions providing essential services to the core business.. Studies have focused on governance structures such as the distribution of the IT authority (e.g. Sambamurthy 
and Zmud, 1999) or the work of steering committees (e.g. Karimi et al., 2000), but also on governance processes such as IT strategy development (e.g. Van Grembergen et al., 2004) or decision making practices (e.g. Sabherwal and King, 1995). Increasing attention is put on informal relationships for controlling and guiding the IT function with studies focusing on networking and HR practices such as liaison roles and the co-location of business and IT staff (C. V. Brown, 1999; Zmud, 1984).

Several governance typologies have been identified (King, 1983; Weill, 2004; Weill and Ross, 2005) that capture prevalent structural and process mechanisms. Governance research in the IT domain focuses on mechanisms that differentiate and integrate the support activities with the core business activities. Considering the extent of governance mechanisms and overarching configurations identified in the IT domain we propose that a range of governance mechanisms and overarching configurations can also be identified for the KM domain.

\section{Proposition 1a: Organizations will use a diversity of governance mechanisms to govern the KM initiative.}

\section{Proposition 1b: Among the diverse governance mechanisms a range of overarching configurations will emerge.}

Contingency theory suggests that organizational phenomena do not emerge in isolation but are related to its organizational context (Donaldson, 2001). Several studies have identified a match between organizational structure and IT governance structure (C. Brown and Magill, 1994; Earl, 1989; Ein-Dor and Segev, 1982; King, 1983; Peterson, 2004b; Sambamurthy and Zmud, 1999; Sujiparapitaya et al., 2003; Tavakolian, 1989). Olson and Chervany (1980) identified a relationship between corporate structure and relational governance mechanisms by observing that IT functions in decentralized organizations are more focused on liaising with users than IT functions in centralized organizations.

Research on the relationship between firm size and IT governance configuration has shown that smaller firms tend to centralize IT governance structures while larger firms decentralize due to the need for increased responsiveness (Ein-Dor and Segev, 1982; Peterson, 2004b; Sambamurthy 
and Zmud, 1999). Larger organizations have also more formalized IT governance processes (IT Governance Institute, 2008). Further studies have highlighted that particular industry types (e.g. banking) are more strategically dependent on zero-defect IT operations than others and therefore put more emphasize on creating IT steering committees (Gupta and Raghunathan, 1989). The financial and IT/telecommunication sectors have a strong emphasis on formalizing their IT governance processes (IT Governance Institute, 2008). Following a contingency theoretical research perspective and the evidence from governance research in the IT domain, relationships between the characteristics of an organization and its KM governance configuration can be expected.

\section{Proposition 2: Aspects of the KM governance configuration are related to the characteristics of the organization.}

The relationship between the governance configuration and the nature of the particular initiatives undertaken has been investigated in a range of related studies. Centralized IT governance configurations lead to a greater standardization of applications, a higher efficiency in operations, and lower costs through economies of scale and more sophisticated management arrangements (A. E. Brown and Grant, 2005; King, 1983; Peterson et al., 2000; Weill and Ross, 2005). Decentralization on the other hand, is associated with better responsiveness to local business needs, greater flexibility for users, better stimulation of business unit creativity, and higher costs. IT steering committees impact on project prioritization, the choice of projects and the overall business alignment of IT programs (McKeen and Guimaraes, 1985; Torkzadeh and Xia, 1992). Given that governance configurations impact on initiatives in related domains we propose a relationship between KM governance configuration and KM program.

\section{Proposition 3: The KM governance configuration is related to the KM program.}

\section{THE RESEARCH}

Multiple case research was identified as a suitable methodology due to the exploratory nature of the above propositions (Benbasat et al., 1987; Yin, 2003). Case selection followed a theoretical 
replication strategy (Yin, 2003) aiming at a variety of industries and firm sizes, important contingency factors identified in prior governance research (e.g. Ein-Dor and Segev, 1982; IT Governance Institute, 2008). To assure suitability, case organizations had to meet three key criteria: 1) creation of explicit KM roles (to assure ample KM program involvement ); 2) active $\mathrm{KM}$ engagement of more than two years (to assure experience with the KM program and associated governance structures); 3) at least two staff had to be willing to participate in the study (to allow for verification of the obtained data). Organizations from Australia, New Zealand and Germany were sought to provide an international perspective (Broadbent et al., 1999) ${ }^{1}$. The twelve case organizations ultimately selected for the research are described in the Appendix 1.

Data collection focused on semi-structured interviews and document review (Yin, 2003). As the research targeted the governance arrangements of the KM function interviews were conducted with KM leaders and KM staff, instead of users of KM services. Interviews focused on the organization's KM program (KM tools and initiatives), the KM governance configuration (mechanisms to execute, support and guide the KM program), and the characteristics of the organization (products and services offered, aspects of organizational structure and culture). A pilot study was conducted prior to data collection. 37 interviews, lasting between 45 minutes and 2.5 hours were conducted transcribed and sent to the interview partners for review and additional clarifications where necessary. Secondary data in the form of presentations, strategy documents, brochures, consulting reports and minutes of meetings were collected from case organizations.

Data analysis focused on initial data processing and subsequent cross-case examination (Miles and Huberman, 1994). Initial processing included the preparation of contact summary sheets, document summary sheets, coding scheme and case write-ups. Following Miles \& Huberman (1994), closed and open coding processes were combined to integrate aspects from the IT governance literature, but also allow for the development of new KM focused codes. The

\footnotetext{
1 The organizations' KM governance arrangements were not compared to each other based on their cultural background. Since many of these organizations were multi-national corporations, identifying and deciding which culture had what kind of influence would have been beyond the scope of this research.
} 
literature based coding scheme was developed and used to code the data from three case organizations. The emergence of additional codes lead to an improved coding scheme which was subsequently used to code all of the transcripts, contact summary sheets and documents in the case database.

Case write-ups were sent to key informants for verification. Subsequent cross-case analysis employed four data display techniques to allow for identification of patterns (Miles and Huberman, 1994): meta matrices (to categorize organizations based on their core characteristics), clustered summary tables (to show the distribution of case organizations based on their governance aspects), summed indices (to integrate governance aspects and identify emerging patterns among the case organizations, and scatterplots (to perform bivariate analysis of relationships and identify clusters).

The data points for cross-case analysis were determined on the basis of the following criteria: organization size was based on employee numbers (following Ahituv et al., 1989); organizational structure was determined following Ahituv et al's (1989) classification scheme (functional structure, product structure, matrix structure). Industry type classification emerged from the case data (manufacturing, public administration, service provider, consulting). KM approaches of the case organizations were determined by an analysis of the tools and processes employed by the organizations as part of their KM programme (following Merono-Cerdan et al., 2007). The classification of KM approaches distinguished between codification approach (organizations which predominantly focus on tools and applications for knowledge storage and exchange); personalisation approach (focus on tools and processes which facilitate tacit knowledge sharing); comprehensive approach (organizations whose KM programme does not emphasise one approach over the other). A summary of the case organizations characterizations is provided in Appendix 1.

\section{KM GOVERNANCE MECHANISMS}

To address Proposition 1a, the analysis identified the various mechanisms that have contributed to the governance of the case organization's KM programs. Following Peterson (2004a, 2004b), 
the diverse mechanisms are grouped into governance structures, processes and relational mechanisms.

\section{KM governance structures}

The analysis identified four important structural aspects that developed and guided the KM programs (Table 1). Distribution of KM authority describes the allocation of KM decision making rights in the organization (centralized, decentralized, federal). KM governance committee refers to a permanent committee which oversees the $\mathrm{KM}$ program and assists in its development ${ }^{2}$, a mechanism which interviewees described as providing critical support for the development of individual KM initiatives. Reporting point of $K M$ emerged as an important aspect from the case data with KM leaders reporting to either support- business functions, or to both simultaneously. Interviewees frequently described how the KM reporting point impacted on the KM program's business integration and collaboration with other support functions. Form of $K M$ group emerged from the case data and captures the type of KM group: standing function, community based KM group or hybrid KM group. The allocation of part-time KM responsibilities (in community based and hybrid KM groups) was described as an important governance mechanism providing opportunities for business alignment and user acceptance due to local presence of KM staff.

\section{KM governance processes}

Four important process aspects were identified that guided the KM program development (Table 2). KM strategy development includes the procedures and methods used for developing an explicit KM strategy. Four case organizations followed a formal KM strategy development while others had no mechanisms for integrating the business perspectives or lacked a KM strategy altogether. KM planning and decision making focuses on the process for approving individual KM initiatives with some organizations establishing working groups to integrate decision makers outside the KM group while others only prioritize KM initiatives within the KM group. The

\footnotetext{
${ }^{2}$ Project based steering committees are not considered in this discussion.
} 
focus on KM reporting and monitoring processes identified a considerable variety in the sophistication through which KM groups give account of their activities. KM funding was identified as an important factor contributing to the control of $\mathrm{KM}$ activities with some $\mathrm{KM}$ groups having set budgets to fund the ongoing services and projects while others have project based budgets where KM groups compete for funding with projects from other areas (including IT).

\section{Table 1. Structural aspects of KM governance (letters A-L depict the case organizations)}

Distribution of KM authority (adopted from C. V. Brown, 1999; Sambamurthy and Zmud, 1999)

- Centralised: KM program authority is held by a centralized organizational body [A, C, E, G, H, B]

- Federal: KM responsibility is shared between a central body and decentralized parts [D, F, K, L]

- Decentralised: KM responsibility is distributed without a central KM authority [I, J].

KM governance groups (adopted from Kahai et al., 2001-2002; Sambamurthy and Zmud, 1999)

- Internal director group: senior management representatives provide advise and execute decision [A, C, K, F]

- Focus group: KM stakeholders identify KM related needs in the organization and provide feedback [B, D*, L]

- Customer group: major users of KM clarify their requirements [D*]

- No governance group [E, G, H, I, J]

Reporting point of KM (emerged from data)

- Support function: KM leader reports to headquarter or support function [B, C, E, G, H, J, K, L]

- Business function: KM leader reports to an operational business function [A]

- Support and Business: KM group members are equally associated with support and business parts of the organization (due to decentralised or federal structures) [D, I, F]

Form of KM organization (emerged from data)

- Standing organization: a permanent, standing function with full-time staff [A, C, E, G, H, B, L]

- Community based organization: staff from various departments are assigned KM responsibilities [I, J]

- Hybrid organization: a combination of standing and community based KM group [D, F, K]

\section{Relational aspects of KM governance}

Three levels of relationships emerged from the case data that contributed to KM program development outside the formal organizational structures and processes (see Table 3): KM staff from three case organizations described how relationships between top management and the KM function provided important guidance and support for KM program development ${ }^{3}$. Personal

\footnotetext{
${ }^{3}$ Available data for $\mathrm{C}$ was insufficient to determine the extent of relational mechanisms between $\mathrm{KM}$ and senior management.
} 
relationships between KM leader and top management (established through prior roles or senior position of the KM leader), and the relationship to KM sponsors (senior management with strong subject matter interest in the KM program) played an important role.

The relational mechanisms between KM function and the business line were found to be critical for nine organizations as they provided members of $\mathrm{KM}$ groups with opportunities to integrate with the business side of the organization and to better respond to their immediate KM needs. Interviewees from all case organizations highlighted the importance of relational mechanisms between KM and other support functions to informally coordinate the KM program objectives. The relationship between KM and IT was of particular importance since KM services often depend on extensive collaboration and efficient support from the IT domain.

\section{Table 2. Process aspects of KM governance (letters A-L depict the case organizations)}

KM strategy development process (adopted from Patel, 2002; Van Grembergen et al., 2004)

- Formal process: KM strategy is based on structured consultation processes, established methodologies and the assistance of outside consultants [C, D , H, I]

- Informal process: KM strategy is done by KM staff and presented to management for approval [A, F , K]

- No strategy: no explicit KM strategy is developed [B , E , G , J , L]

Planning and decision making process (adopted from Sabherwal and King, 1992, 1995)

- Externally focused: outside stakeholders participate in selection of KM services and projects [E, G, L, J, I, A]

- Internally focused: projects selection by KM group with limited stakeholder participation.[D, C, F, H, K, B]

Reporting and monitoring process (adopted from Ali, 2006; Karimi et al., 2000)

- Advanced reporting: advanced reporting processes determine the business value of KM [C]

- Basic reporting: reporting is limited to standard performance indicators [A, B, D, E, F, G, H, K, L]

- No formal reporting: no formal processes account for the organizational KM program [I, J] Funding process (adopted from Olson and Chervany, 1980)

- Fixed budget: set KM budget for ongoing services and most projects. Only for larger infrastructure related projects additional funds are provided [A, C, D, E, G, H, L* (partly budget available)]

- Project based budget: very little general KM funding is provided and projects are resourced by organizationwide funds [F, J, K]

- User provides budget: no KM funding is provided by the organization and user departments have to provide resources $\left[\mathrm{L}^{*}\right.$ (partly no budget available), B, I].

*= different funding practices within federal entities. Categories derived from case data

Our analyses has identified a diversity of mechanisms that contribute to the governance of the organizational KM programs. While some of these mechanisms describe dedicated formal structures and processes, other mechanisms refer to informal relationship-based mechanisms. This evidence provides substantial support for Proposition 1a. 


\section{Table 3. Relational aspects of KM governance (letters A-L depict the case organizations)}

KM:Top management (emerged from data)

- Personal network KM leader: personal relationships between the KM leader(s) and senior management member(s) assists in KM program development [D, E, H]

- KM sponsor: senior managers with interest into KM (without formal responsibility) provide valuable political support $[\mathrm{D}, \mathrm{E}]$

Insufficient data available for categorizing $\mathrm{C}$

KM:Business (adopted from Blanton et al., 1992; C. V. Brown, 1999; Zmud, 1984)

- Physical co-location: placing KM personnel with business staff supports business integration [G, $\mathrm{F}^{*}, \mathrm{I}^{*}, \mathrm{D}^{*}$ $(*=$ co-located due to the decentral or federal structure of $\mathrm{KM})]$

- Account management: individual KM staff focusing on particular clients leads to close working relationship and business integration $[\mathrm{A}, \mathrm{C}, \mathrm{G}]$

- Frequent operational interaction: provision of ongoing KM services (not discreet KM projects) create strong relational ties between KM function and business. [A, C, E, H, B]

- Personal network KM leader: KM leaders with previous roles in the business side of the organization contribute to the KM program development. [F, (I)]

KM:Support function (emerged from data)

- Physical co-location: placing KM personnel with other support staff creates opportunities for integration [H (KM and IT are integrated in a joint function), D, J (staff with KM responsibilities have roles within support functions)]

- Liaison roles: liaison responsibilities support KM program development[F (KM \& IT), A (KM \& IT), C (KM $\&$ IT)]

- Staff transfer: personnel transfer between KM function and other support functions improves integration of initiatives [A (KM \& IT), G (KM \& IT)]

- Personal network KM leader: KM leader's personal network supports integration between KM and support functions (esp. IT functions) [E (KM \& IT)]

- Integration KM leader in other initiatives: integrating KM leaders with other organizational initiatives contributes to integration of KM function with other support functions. [H (between KM \& IT), D, F, H, L (partly), K, E (KM leader is also process and quality manager)]

\section{TYPOLOGIES OF KM GOVERNANCE}

To address Proposition $1 \mathrm{~b}$ the analysis identified the range of overarching KM governance configurations evident in the twelve case organizations. Typologies aggregate the diverse structural, process and relational KM governance aspects previously identified. To develop a typology of KM governance structures the 'distribution of authority' was used as distinguishing criteria following examples in the literature (C. Brown, 1997). Table 4 shows a high level of consistency among the distribution of authority and other structural KM governance aspects, supporting its appropriateness as the basis for a KM governance structure typology. 


\section{Table 4: Typology of KM governance structures}

Organization

Centralised KM: KM responsibility is focused within a single organizational entity

- all centralised KM functions are established as standing function (6/6)

- centralised KM functions are largely headquarter support functions (5/6)

- centralised KM functions are unspecific regarding governance groups (3/6)

Federal KM: KM responsibility is shared between a central organizational entity and distributed divisions or business groups in the organization

- most federal KM functions are established in hybrid form (3/4)

- most federal KM functions are distributed between headquarter and organization (3/4)

- most federal KM functions have governance group (3/4)

Decentralised KM: KM responsibility is shared between different divisions or business groups

- all federal KM functions are community based (2/2)

- no federal KM function has established governance groups (2/2)

- federal KM functions are unspecific regarding position in organization $(1 / 2)$

$(\mathrm{x} / \mathrm{y})=>\mathrm{x}$ out of $\mathrm{y}$ organizations

A KM governance process typology was derived on the basis of the IT governance maturity model (IT Governance Institute, 2003). The notion of KM governance maturity levels follows other maturity models (e.g. De Haes and Van Grembergen, 2004) with the assumption that higher maturity levels provide more sophisticated control and guidance to the KM program. Table 5 shows five KM governance maturity levels which are based on the sophistication of the governance processes. The 12 case organizations were categorized based on their existing KM governance processes.

\begin{tabular}{|l|l|}
\hline Table 5: Typology of KM governance process & Organizations \\
\hline $\begin{array}{l}\text { Managed and measurable: KM governance processes for strategic integration of KM are } \\
\text { established. Reporting processes focus on determining the KM business impact. }\end{array}$ & C \\
\hline $\begin{array}{l}\text { Defined process: Clear and formal KM governance processes allow for strategic integration of } \\
\text { KM, but reporting does not reflect the KM business impact. }\end{array}$ & D, H \\
\hline $\begin{array}{l}\text { Repeatable but intuitive: Senior management and business are involved in the KM program, } \\
\text { but mostly focused on individual projects instead of strategic integration. }\end{array}$ & F, K, A \\
\hline $\begin{array}{l}\text { Ad-hoc: The need for senior management involvement and business integration of KM has } \\
\text { been recognised, but is only realised on an ad-hoc basis. }\end{array}$ & B, G, L, E \\
\hline $\begin{array}{l}\text { Informal: KM governance lacks formal processes. Little senior management and business } \\
\text { involvement has been established. }\end{array}$ & I, J \\
\hline
\end{tabular}

To capture differences among relational mechanisms a typology was developed that categorize the case organizations based on the scope of their relational KM governance mechanisms. The 
typology differentiates between a comprehensive KM governance network, a business and support focused network, and a support focused network (see Table 6).

\begin{tabular}{|l|l|}
\hline Table 6: Typology of relational mechanisms & Organizations \\
\hline $\begin{array}{l}\text { Comprehensive network: KM program benefits from all three sets of informal relationships: } \\
\text { KM:top management, KM:business, KM:support function. }\end{array}$ & D, E, H \\
\hline $\begin{array}{l}\text { Business and support network: only informal relationships between KM:business, } \\
\text { KM:support function. KM groups use relational mechanisms such as account management } \\
\text { roles, physical co-location or frequent operational interaction to facilitate integration with } \\
\text { business or support side of the organization. }\end{array}$ & I \\
\hline $\begin{array}{l}\text { Support focused network: only informal relationships between KM and other support } \\
\text { functions. }\end{array}$ & J, K, L \\
\hline
\end{tabular}

Identifying the overarching configurations among the diversity of governance mechanisms satisfies Proposition 1b. An assessment of the case organizations confirms the independence of the resulting typologies, as only two case organizations (B, G) share KM governance categories across all three dimensions.

\section{KM GOVERNANCE CONFIGURATIONS}

The analysis of the relationship between organizational characteristics and KM governance configuration (Proposition 2) draws on the three typologies developed above. Scatterplots were identifyied the following patterns: Case organizations that were based on a matrix structure had established the highest KM governance maturity levels and, in addition, were found to make extensive use of KM governance committees. Larger case organizations had generally developed a higher level of KM governance sophistication and tend to establish KM governance committees more frequently than smaller ones. Analysis of industry types showed that the consulting firms exhibited particularly high KM governance maturity and showed greater consistency in the way they positioned $\mathrm{KM}$ as a separate support function. Identifying the patterns between KM governance and organizational context validates proposition 2 .

The analysis of the relationship between each organization's KM governance configuration and its KM approach (proposition 3) draws on the categorization of codification focused, 
personalization focused or comprehensive KM approaches (Choi and Lee, 2003). The analysis showed that most case organizations that had adopted a codification focused approach had also established a centralized KM governance structure. Organizations with a codification-focused KM approach tended to maintain a standing KM group, which reported into a headquarters-based support function. On the other hand, organizations that had adopted a personalization approach exhibited few formal KM governance processes and had a low KM governance maturity level. Patterns which could be identified between KM governance and KM program validate Proposition 3.

\section{DisCuSSION}

The importance of knowledge as a critical resource is widely recognized, but the kind of knowledge related initiatives organizations should engage in, is still heavily debated and subject to extensive research (Maier, 2007). The present study focuses on the mechanisms that are in place to guide the development of a KM program, instead of investigating the viability of particular programs. The study follows the notion that guiding and control mechanisms are critical as they ensure that the organizational program develops to the requirements of the organization. The analysis has identified a range of such governance mechanisms which are presented in Table 7 in form of a KM governance framework. The framework summarizes the relevant control and guiding mechanisms encountered in the case organizations. The identification of the mechanisms allowed us to systematically compare and categorise the KM governance configurations and identify their patterns. The KM governance framework and its individual mechanisms are subsequently discussed in more detail.

Table 7. A framework of KM governance for practice and research

\begin{tabular}{|l|l|}
\hline $\begin{array}{l}\text { Structural KM governance } \\
\text { mechanisms }\end{array}$ & $\begin{array}{l}\text { Level of centralization } \\
\text { Reporting point of KM } \\
\text { Status of KM staff } \\
\text { Advisory groups }\end{array}$ \\
\hline $\begin{array}{l}\text { Procedural KM governance } \\
\text { mechanisms }\end{array}$ & KM strategy \\
& Process for planning \& decision making KM \\
& Arrangements for reporting \& monitoring KM \\
& Budget source \\
\hline
\end{tabular}




\begin{tabular}{|l|l|}
\hline Relational KM governance & Personal network KM leader \\
mechanisms & KM sponsor \\
& Physical collocation \\
& Account management structure \\
& Staff transfer schemes \\
& Frequent operational interaction \\
& Liaison roles \\
& Staff transfer \\
& Communities of practice \\
& Integration KM leader in other initiatives \\
\hline
\end{tabular}

KM governance mechanisms are organizational design instruments that seek to differentiate and integrate between the $\mathrm{KM}$ program and the organization. Differentiation contributes to the independence and visibility of the KM program while integration contributes to its responsiveness to business needs. A centralised, standing KM group creates a differentiation between KM program and organization while a decentralised and community-based KM group blurs the boundaries and contributes to their integration. The establishment of KM governance groups contributes to integration and exchange between KM and the organization. The KM reporting structure can contribute to integration (KM leader reports into a business function) but also differentiation (KM leader reports into a support function).

The KM governance processes summarized in the KM governance framework above largely contribute to the integration between KM program and the organization. However, the extent of integration depends on the sophistication of their implementation. A KM strategy, for example, can be developed through a formal process including a systematic consultation with the wider organization, or can be informally developed with input limited to the members of the KM group. Also, planning and decision making for individual KM initiatives can either be done by stakeholders of KM services in the wider organization, or by members of the KM group. Encouraging input from external stakeholders into KM strategy development and decision making is likely to contribute to the business integration of the KM program.

Throughout the study interview participants have highlighted the importance of relational mechanisms and their contribution to integration between KM program and the organization. Participants described how relationships outside the formal governance structure were crucial in 
understanding business needs and priorities, and assisted in obtaining funding and political support. Relational mechanisms were even reported to bridge the gap between a centralized KM group and the wider organization (Organization E). Relational mechanisms also supported the integration between KM and the other support functions. Such integration is critical as KM is a meta discipline which integrates tools and concepts from other established disciplines (such as IT, HR and organizational strategy, Raub and Rüling, 2001), and extensive coordination with other support functions is crucial. A number of interview participants emphasised the critical nature of the relationship between KM and IT, since IT is integral to the success or failure of many KM initiatives.

\section{Patterns of KM governance}

The KM governance framework and its components were used to identify patterns between the KM governance configuration and the organizational environment. The industry-type analysis showed an overall high KM governance maturity among consulting firms which is likely related to the high emphasis consulting organizations put on knowledge-related business processes and infrastructure (Hansen et al., 1999). The consulting industry was also among the first to embrace KM (Smith and McKeen, 2003) which has led to the establishment of more sophisticated governance mechanisms. The finding that smaller case organizations exhibited lower levels of governance maturity is not necessarily unique to the KM domain as research in other domains have shown that organizations generally develop more formalized governance processes as part of their growth process (Miller, 1987). The increased formality and greater use of KM governance committees observed in larger case organizations corresponds with findings from the

IT literature, which has similarly shown that large organizations have more formalized planning practices (Doll and Torkzadeh, 1987) and more frequently rely on governance committees than do small organizations (Torkzadeh and Xia, 1992).

The investigation of the relationship between KM governance configurations and KM programs among the case organizations has provided further insights into the development of a KM program. Personalization focused KM programs were observed to exhibit particularly low levels of KM governance sophistication, which is likely to be explained by the different investment levels required for different $\mathrm{KM}$ programs and considerations of organizational risks. A 
codification based KM program requires a sizeable technological infrastructure (e.g., centralized knowledge databases), which consumes considerably more funds than a personalization-based KM program that focuses on localized interventions and specific solutions. Organizations, which adopt knowledge repositories tend to become highly dependent on them to refer to past projects, obtain best practice recommendations or review specific guidelines. Any disruption of such a repository would have an immediate effect on the core business processes. In contrast, a disruption to a personalization-based KM program would have much less noticeable impact. As organizations seek to minimize risks, more sophisticated governance processes are established for codification-focused KM programs.

The analysis further showed that case organizations developing a codification based KM program tend to employ a centralized KM governance structure. A central function not only provides economy of scale (Sambamurthy and Zmud, 1999), but also best supports knowledge distribution and reuse, the core objectives of a codification-focused KM program (Hansen et al., 1999). Further, knowledge repositories benefit from extensive use: a larger range of content

provides greater benefits for the individual user (given the content is of appropriate quality). A centralization strategy has been shown as the best organizational form to establish and enforce the standards required for such organization-wide usage (A. E. Brown and Grant, 2005).

\section{CONCLUSIONS AND IMPLICATIONS}

Although large numbers of organizations have established dedicated KM programs, little is known about the mechanisms which direct and guide these KM programs. To play an effective role, $\mathrm{KM}$ programs need to be integrated into organisational practice but at the same time differentiated to ensure that they maintain a visible agenda. Invisible KM programs will find it difficult to attract the interest and support required. An organisation's KM governance captures the structures, processes and relational mechanisms which integrated and differentiate between the KM program and the wider organisation.

This research set out to systematically identify and compare KM governance configurations in a range of organizations. A framework that illustrates the diversity of KM governance mechanisms 
was developed and patterns between KM governance, organizational characteristics and KM program were identified. The findings need to be considered in the light of the study's limitations. The current lack of explicit KM governance theory required an exploratory research to develop the foundation for further hypothesizing and theorizing. Adopting a contingency based perspective on governance means no clear statements about causality can be provided (Markus, 1988). While relational pattern between the KM governance and KM program were observed we cannot clearly identify the exact nature of this relationship and cannot exclude coevolutionary processes or mutual influences between the different factors considered (Venkatraman, 1989). Even though we included a large number of cases the findings need to be viewed in the general context of qualitative research with its limited generalizability (Yin, 2003).

Despite its limitations the study makes a range of important contributions and opens up several opportunities for future research. One of the main contributions is the establishment of a KM governance framework that showcases the diverse mechanisms that guide and control organizational KM programs. The framework allows for a systematic analysis of KM governance based patterns and relationships. Based on the framework future research should investigate factors such as organizational strategy, organizational culture or national culture with their impact on KM governance configuration. With the current study focusing on European and Australasian companies future research should include US based companies to increase the generalizability of the findings. An important extension of the present research would be the inclusion of success measures to identify the governance configurations best suitable for particular organizational considerations. The present study provides the basis for a range of future research opportunities that advance understanding of $\mathrm{KM}$ and its practice in organizations.

In addition to stimulating future research the present study provides immediate value to KM practice. Organizations have been very enthusiastic about implementing KM tools and practices, but the overall organizational structures in which KM programs are embedded and the mechanisms guiding these programs were of less concern. The present research helps to draw attention from the immediate aspects of the KM initiative to the larger context of its governance. The research raises awareness about the diversity of viable governance mechanisms in KM as well as the impact individual governance aspects can have on a KM program. Management is 
advised to consider the possible implications and benefits individual mechanisms such as the $\mathrm{KM}$ reporting point or the establishment of steering groups can have on the development of the $\mathrm{KM}$ program and the political support it is likely to receive.

Of particular concern for management should be the range of relational mechanisms identified in this study. Relational mechanisms can effectively complement existing governance structures and processes and create opportunities without the need for organizational restructuring or process changes. Management should identify and strengthen existing relationships between the $\mathrm{KM}$ function and the wider organization, as well as identify opportunities for the development of new relationships. The range of specific relational mechanisms identified in this research provide valid instruments for supporting these relationships and should be considered for implementation in the light of the specific organizational context and nature of the KM program.

\section{REFERENCES}

Ahituv, N., Neumann, S. and Zviran, M. (1989), "Factors affecting the policy for distributing computing resources", MIS Quarterly, Vol. 13, No. 4, pp. 388-402.

Akhavan, P., Jafari, M. and Fathian, M. (2006), "Critical success factors of knowledge management systems: a multi-case analysis", European Business Review, Vol. 18, No. 2, pp. 87-113.

Alazmi, M. and Zairi, M. (2003), "Knowledge management critical success factors", Total Quality Management, Vol. 14, No. 2, pp. 109-204.

Ali, S. (2006), "Effective Information Technology Governance Mechanisms", Gadjah Mada International Journal of Business, Vol. 8, No. 1, pp. 69-102.

Benbasat, I., Goldstein, D. K. and Mead, M. (1987), "The case research strategy in studies of information systems", MIS Quarterly, Vol. 11, No. 3, pp. 369-386.

Blanton, J. E., Watson, H. J. and Moody, J. (1992), "Toward a better understanding of information technology organization: A comparative case study", MIS Quarterly, Vol. 16, No. 4, pp. 531-555.

Broadbent, M., Weill, P. and Neoc, B. S. (1999), "Strategic context and patterns of IT infrastructure capability", The Journal of Strategic Information Systems, Vol. 8, No. 2, pp. 157-187.

Brown, A. E. and Grant, G. G. (2005), "Framing the frameworks: A review of IT governance research", Communications of the AIS, Vol. 15, No., pp. 696-712.

Brown, C. (1997), "Examining the emergence of hybrid IS governance solutions: Evidence from a single case site", Information Systems Research, Vol. 8, No. 1, pp. 69-94. 
Brown, C. and Magill, S. L. (1994), "Alignment of the IS Functions with the Enterprise: Toward a Model of Antecedents", MIS Quarterly, Vol. 18, No. 4, pp. 371-403.

Brown, C. V. (1999), "Horizontal mechanisms under differing IS organization contexts", MIS Quarterly, Vol. 23, No. 3, pp. 421-454.

Call, D. (2005), "Knowledge management - not rocket science", Journal of Knowledge Management, Vol. 9, No. 2, pp. 19-30.

Choi, B. and Lee, H. (2003), "An empirical investigation of KM styles and their effect on corporate performance", Expert Systems with Applications, Vol. 40, No. 5, pp. 403-417.

Chua, A. and Lam, W. (2005), "Why KM projects fail: a multi-case analysis", Journal of Knowledge Management, Vol. 9, No. 3, pp. 6-17.

Coakes, E. (2002). Knowledge management: A sociotechnical perspective. In E. Coakes, D. Willis \& S. Clarke (Eds.), Knowledge Management in the SocioTechnical World (pp. 4-14). London: Springer-Verlag.

Davenport, T. H. and Prusak, L. (1998), Working knowledge: How organizations manage what they know. Harvard Business School Press, Boston, MA.

De Haes, S. and Van Grembergen, W. (2004). "IT Governance and its mechanisms", Information Systems Control Journal, Vol. 1.

Desouza, K. C. and Awazu, Y. (2006), "Engaging tensions of knowledge management control", Singapore Management Review, Vol. 28, No. 1, pp. 1-13.

Doll, W. J. and Torkzadeh, G. (1987), "The relationship of MIS steering committee to size of firm and formalization of MIS planning", Communications of the ACM, Vol. 30, No. 11, pp. 972-978.

Donaldson, L. (2001), The contingency theory of organizations. Sage Publications, Thousand Oaks.

Drucker, P. (1993), Post-Capitalist Society. Butterworth Heinemann, Oxford.

Earl, M. J. (1989), Management strategies for information technology. Prentice Hall, Englewood Cliffs, NJ.

Ein-Dor, P. and Segev, E. (1978), "Organizational Context and the Success of Management Information Systems", Management Science, Vol. 24, No. 10, pp. 1064-1077

Ein-Dor, P. and Segev, E. (1982), "Organizational context and MIS structure: Some empirical evidence", MIS Quarterly, Vol. 6, No. 3, pp. 55-69.

Galbraith, J. (1973), Designing complex organizations. Addison-Wesley, Reading, MA.

Galliers, R. D. and Newell, S. (2003), "Back to the future: from knowledge management to the management of information and data", Journal of Information Systems and E-Business Management, Vol. 1, No. 1, pp. 513.

Grolik, S., Kalmring, D., Lehner, D. and Frigerio, C. (2003). Analysis of interrelations between business models and knowledge management strategies in consulting firms. Paper presented at the ECIS.

Gupta, Y. P. and Raghunathan, T. S. (1989), "Impact of information systems (IS) steering committees on IS planning", Decision Sciences, Vol. 20, No. 4, pp. 777-793.

Hansen, M. T., Nohria, N. and Tierney, T. (1999), "What's your strategy for managing knowledge?", Harvard Business Review, Vol. 77, No. March-April, pp. 106-116. 
Holden, N. J., (2004), "National culture and diversity of knowledge-sharing styles", Paper presented at the KMAP 2004, Taipei.

IT Governance Institute. (2003). Board Briefing on IT Governance. Retrieved 15. March, 2011, from http://www.itgi.org

IT Governance Institute. (2008). IT governance global status report. Retrieved 17 January, 2011, from http://www.itgi.org

Kahai, P., Snyder, C. A. and Charr, H. H. (2001-2002), "Decentralizing the IS function: Resources and locus of decisions", Journal of Computer Information Systems, Vol. 42, No. 2, pp. 44-51.

Kannabiran, G. and Pandyan, C. (2010), "Enabling role of governance in strategizing and implementing KM", Journal of Knowledge Management, Vol. 14, No. 3, pp. 335-347.

Karimi, J., Bhattacherjee, A., Gupta, Y. P. and Somers, T. M. (2000), "The effects of MIS steering committees on information technology management sophistication", Journal of Management Information Systems, Vol. 17, No. 2, pp. 207-230.

King, J. L. (1983), "Centralized versus decentralized computing: Organisational considerations and management options", Computing Surveys, Vol. 15, No. 4, pp. 319-349.

Lawrence, P. R. and Lorsch, J. W. (1967), "Differentiation and Integration in Complex Organizations", Administrative Science Quarterly, Vol. 12, No. 1, pp. 1-47.

Liebeskind, J. P. (1996), "Knowledge, strategy, and the theory of the firm", Strategic Management Journal, Vol. 17, No. Winter special issue, pp. 93-107.

Maier, R. (2007), Knowledge Management Systems: Information and Communication Technologies for Knowledge Management. Springer Verlag, Berlin.

Markus, M. L. (1988), "Information technology and organizational change: Causal structure in theory and research", Management Science, Vol. 34, No. 5, pp. 583-598.

Mason, D. and Pauleen, D. (2003), "Perceptions of Knowledge Management: A qualitative analysis", Journal of Knowledge Management, Vol. 7, No. 4, pp. 38-48.

Mathiassen, L. and Sørensen, C. (2008), "Towards a theory of organizational information services", Journal of Information Technology, Vol. 23, No., pp. 313-329.

McKeen, J. D. and Guimaraes, T. (1985), "Selecting MIS projects by steering committee", Communications of the ACM, Vol. 28, No. 12, pp. 1344-1352.

Merono-Cerdan, A. L., Lopez-Nicolas, C. and Sabater-Sanchez, R. (2007), "Knowledge management strategy diagnosis from KM instruments use", Journal of Knowledge Management, Vol. 11, No. 2, pp. 60-72.

Miles, M. B. and Huberman, M. A. (1994), Qualitative data analysis: an expanded sourcebook. SAGE Publications, Inc., Thousand Oaks, California.

Miller, D. (1987), "The Genesis of Configuration", Academy of Management Review, Vol. 12, No. 4, pp. 686-701.

Nonaka, I. (1994), "A dynamic theory of organizational knowledge creation", Organization Science Vol. 5, No. 1, pp. 14-37. 
Olson, M. H. and Chervany, N. L. (1980), "The relationship between organizational characteristics and the structure of the information services function", MIS Quarterly, Vol. 4, No. 2, pp. 57-68.

Patel, N. V. (2002), "Emergent forms of IT governance to support global e-business models", Journal of Information Technology Theory and Applications, Vol. 4, No. 2, pp. 33-48.

Peterson, R. R. (2004a), "Crafting information technology governance", Information Systems Management, Vol. 21, No. 4, pp. 7-21.

Peterson, R. R. (2004b). Integration strategies and tactics for information technology governance. In W. Van Grembergen (Ed.), Strategies for Information Technology Governance (pp. 37-80). Hershey: IDEA Group Publishing.

Peterson, R. R., O'Callaghan, R. and Ribbers, P. M. A., (2000), "Information technology governance by design: Investigating hybrid configurations and integration mechanisms", Paper presented at the ICIS, Brisbane, Australia.

Plessis, M. d. (2007), "Drivers of knowledge management in the corporate environment", Journal of Knowledge Management, Vol. 11, No. 2, pp.

Raub, S. and Rüling, C.-C. (2001), "The knowledge management tussle - speech communities and rhetorical strategies in the development of knowledge management", Journal of Information Technology, Vol. 16, No. 2, pp. 113-130.

Riege, A. (2005), "Three dozen knowledge sharing barriers managers must consider", Journal of Knowledge Management, Vol. 9, No. 3, pp. 18-35.

Sabherwal, R. and King, W. R. (1992), "Decision processes for developing strategic applications of information systems: A contingency approach", Decision Sciences, Vol. 23, No. 4, pp. 917-943.

Sabherwal, R. and King, W. R. (1995), "An empirical taxonomy of the decision-making processes concerning strategie applications of information systems", Journal of Management Information Systems, Vol. 11, No. 4, pp. 177-214.

Sambamurthy, V. and Zmud, R. W. (1999), "Arrangements for information technology governance: A theory of multiple contingencies", MIS Quarterly, Vol. 23, No. 2, pp. 261-290.

Schroeder, A. and Pauleen, D. (2007), "KM Governance: Investigating the case of a knowledge intensive research organisation", Journal of Enterprise Information Management, Vol. 20, No. 4, pp. 414-431.

Schroeder, A., Pauleen, D. and Huff, S. (2009), "Emerging evidence on linkages between knoweldge management (KM) governance and management strategy: the case of two organizations", International Journal of Knowledge Management Studies, Vol. 3, No. 1/2, pp. 4-21.

Smith, H. A. and McKeen, J. D. (2003). Knowledge Management in Organizations: The State of Current Practice. In C. W. Holsapple (Ed.), Handbook on Knowledge Management (pp. 395-410). New York: Springer-Verlag.

Storey, J. and Barnett, E. (2000), "Knowledge management initiatives: Learning from failure", Journal of Knowledge Management, Vol. 4, No. 2, pp. 145-156.

Sujiparapitaya, S., Janz, D. B. and Gillenson, M. (2003), "The contribution of IT governance solutions to the IT implementation of Data Warehouse Practice", Journal of Database Management, Vol. 14, No. 2, pp. 52-69. 
Suresh, J. K. and Mahesh, K. (2006), Ten steps to maturity in KM. Chandos Publishing, Oxford.

Tavakolian, H. (1989), "Linking the information technology structure with organizational competitive strategy: A survey", MIS Quarterly, Vol. 13, No. 3, pp. 308-318.

Torkzadeh, G. and Xia, W. (1992), "Managing telecommunications by steering committee", MIS Quarterly, Vol. 16, No. 2, pp. 187-199.

Van Grembergen, W., De Haes, S. and Guldentops, E. (2004). Structures, processes and relational mechanisms for IT governance. In W. Van Grembergen (Ed.), Strategies for Information Technology Governance (pp. 137). Hershey, PA: Idea Group Publishing.

Venkatraman, N. (1989), "The concept of fit in strategy research: Toward verbal and statistical correspondence", Academy of Management Review, Vol. 14, No. 3, pp. 423-444.

Weill, P. (2004), "Don't just lead, govern: How top-performing firms govern IT", MIS Quarterly Executive, Vol. 3, No. 1, pp. 1-17.

Weill, P. and Ross, J. (2005), "A matrixed approach to designing IT governance", MIT Sloan Management Review, Vol. 46, No. 2, pp. 26-34.

Wiig, K. (2000). Knowledge management: An emerging discipline rooted in a long history. In D. Charles \& D. Chauvel (Eds.), Knowledge horizons: the present and the promise of knowledge management (pp. 3-26). Woburn, MA: Butterworth-Heinemann.

Wong, K. Y. (2005), "Critical success factors for implementing knowledge management", Industrial Management + Data Systems, Vol. 105, No. 3, pp. 261-279.

Yin, R. B. (2003), Case Study Research: Design and Methods (3rd ed.). Sage Publications, Inc., Thousand Oaks, CA.

Zmud, R. W. (1984), "Design alternatives for organizing information systems activities", MIS Quarterly, Vol. 8, No. 2, pp. 79-93.

Zyngier, S. (2005). Knowledge Management Governance. In D. Schwarz (Ed.), The Encyclopaedia of Knowledge Management (pp. 1-8). Hershey, PA: Idea Group Publishing.

Zyngier, S., Burstein, F. and McKay, J., (2004), "Knowledge management governance: A multifaceted approach to organisational decision and innovation support", Paper presented at the International Conference on Decision Support Systems, Prato, Italy.

Zyngier, S., Burstein, F. and McKay, J. (2005). Governance of Strategies to Manage Organizational Knowledge - a mechanism to oversee knowledge needs. In M. Jennex (Ed.), Case Studies in Knowledge Management (pp. 83-103). Hershey, PA: Idea Group Books.

Zyngier, S., Burstein, F. and McKay, J., (2006), "The Role of Knowledge Management Governance in the Implementation of Strategy", Paper presented at the 39th Hawaii International Conference on System Sciences, Hawaii. 


\section{APPENDIX 1: CASE ORGANIZATIONS}

\begin{tabular}{|c|c|c|}
\hline Organization & $\begin{array}{l}\text { Industry type } \\
\text { Firm size, } \\
\text { Organizational } \\
\text { structure, } \\
\text { KM approach }\end{array}$ & Interviews \\
\hline $\begin{array}{l}\text { A: Australasia based raw material manufacturer with around 20,000 internationally distributed } \\
\text { staff. The KM program has been initiated } 4 \text { years ago and includes business intelligence and } \\
\text { research services, the management of a collaboration platform and in-house consulting services. }\end{array}$ & $\begin{array}{l}\text { Manufacturer, } \\
20,000, \\
\text { Product structure, } \\
\text { Comprehensive approach }\end{array}$ & $\begin{array}{l}\text { KM team manager }(1 \mathrm{hr}) \text {, } \\
\text { KM team manager }(1.5 \mathrm{hrs}) \text {, } \\
\text { KM leader }(1 \mathrm{hr})\end{array}$ \\
\hline $\begin{array}{l}\text { B: Europe based high tech manufacturer with around } 40,000 \text { internationally distributed staff. The } \\
\text { organization had been maintaining a KM program for } 6 \text { years focusing on organizing and } \\
\text { facilitating of knowledge sharing events and communities of practices. }\end{array}$ & $\begin{array}{l}\text { Manufacturer, } \\
40,000, \\
\text { Product structure, } \\
\text { Personalisation approach }\end{array}$ & $\begin{array}{l}\text { KM leader }(1 \mathrm{hr}) \\
\text { KM representative }(1 \mathrm{hr}) \\
\mathrm{KM} \text { staff }(1.5 \mathrm{hrs}) \\
\text { Former } \mathrm{KM} \text { leader }(1.5 \mathrm{hrs})\end{array}$ \\
\hline $\begin{array}{l}\text { C: International technology consulting organization with around 50,000 staff. The KM program ad } \\
\text { been in place for } 10 y e a r s \text { focusing on the management of the knowledge repository and the } \\
\text { provision of research services. }\end{array}$ & $\begin{array}{l}\text { Consulting, } \\
50,000, \\
\text { Matrix structure, } \\
\text { Codification approach }\end{array}$ & $\begin{array}{l}\text { KM staff (2 hrs), } \\
\text { KM team manager (1 hr), } \\
\text { KM staff (1.5 hrs) }\end{array}$ \\
\hline $\begin{array}{l}\text { D: Europe based technology consulting organization with around 30,000 staff. The KM program } \\
\text { had been initiated } 7 \text { years ago and focuses on the management of the knowledge repository and } \\
\text { collaboration system. }\end{array}$ & $\begin{array}{l}\text { Consulting, } \\
30,000, \\
\text { Matrix structure, } \\
\text { Comprehensive approach }\end{array}$ & $\begin{array}{l}\text { Former KM leader (1.5 hrs) } \\
\text { KM leader (1.5 hrs) }\end{array}$ \\
\hline $\begin{array}{l}\text { E: Europe based technology consulting organization with around } 500 \text { staff. The KM program had } \\
\text { been in place for } 6 \text { years and is focused on the management of the knowledge repository and the } \\
\text { provision of research services. }\end{array}$ & $\begin{array}{l}\text { Consulting, } \\
700, \\
\text { Product structure, } \\
\text { Codification approach }\end{array}$ & $\begin{array}{l}\text { KM leader (1.5 hrs) } \\
\text { KM staff (1.5 hrs) }\end{array}$ \\
\hline $\begin{array}{l}\text { F: Europe based technology and policy consulting organization with more than } 1000 \text { staff. The } \\
\text { KM program had been initiated } 6 \text { years ago and focuses on management of the KM system and } \\
\text { projects targeted at reengineering of business processes. }\end{array}$ & $\begin{array}{l}\text { Consulting, } \\
10000, \\
\text { Product structure, } \\
\text { Codification approach }\end{array}$ & $\begin{array}{l}\text { KM representative (1.5 hrs), } \\
\text { KM leader }(2.5 \text { hrs }) \text {, } \\
\text { KM staff }(1 \mathrm{hr})\end{array}$ \\
\hline $\begin{array}{l}\text { G: Australasia based consulting organization with around } 500 \text { staff distributed over a number of } \\
\text { offices. The KM program is operating since } 10 \text { years focusing on the knowledge repository and } \\
\text { research services. }\end{array}$ & $\begin{array}{l}\text { Consulting, } \\
600, \\
\text { Product structure, }\end{array}$ & $\begin{array}{l}\text { KM leader (3 hrs), } \\
\text { KM staff (1.5 hrs) }\end{array}$ \\
\hline
\end{tabular}




\begin{tabular}{|c|c|c|}
\hline & Codification approach & \\
\hline $\begin{array}{l}\text { H: Australasia based public administration with around } 200 \text { collocated staff. The KM approach } \\
\text { had been initiated } 6 \text { years ago and focuses on the provision of research services and the } \\
\text { management and provision of KM tools for the organization. }\end{array}$ & $\begin{array}{l}\text { Public administration, } \\
300, \\
\text { Functional structure, } \\
\text { Codification approach }\end{array}$ & $\begin{array}{l}\text { KM staff }(1 \mathrm{hr}) \text {, } \\
\text { KM team manager }(1.5 \mathrm{hrs}), \mathrm{KM} \\
\text { leader }(1 \mathrm{hr}), \mathrm{KM} \text { team leader } \\
(1.5 \mathrm{hrs}), \mathrm{HR} \text { leader }(1 \mathrm{hr}), \mathrm{KM} \\
\text { staff }(1 \mathrm{hr})\end{array}$ \\
\hline $\begin{array}{l}\text { I: Australasia based public administration with around } 300 \text { collocated staff. The KM program had } \\
\text { been in place since } 7 \text { years focusing on promoting good knowledge sharing practices and provides } \\
\text { assistance in the use of knowledge sharing tools. }\end{array}$ & $\begin{array}{l}\text { Public administration, } \\
400, \\
\text { Functional structure, } \\
\text { Personalisation approach }\end{array}$ & $\begin{array}{l}\text { KM representative }(1.5 \mathrm{hrs}) \\
\text { KM representative }(1 \mathrm{hr})\end{array}$ \\
\hline $\begin{array}{l}\text { J: Europe based industrial service provider with around } 3000 \text { mostly collocated staff. The KM } \\
\text { program is } 3 \text { years old and focuses on the development of individual KM tools (intranet, } \\
\text { wikiserver). }\end{array}$ & $\begin{array}{l}\text { Services Provider, } \\
3000, \\
\text { Product structure, } \\
\text { Codification approach } \\
\end{array}$ & $\begin{array}{l}\text { KM representative }(1.5 \mathrm{hrs}) \\
\text { KM representative }(1.5 \mathrm{hrs}) \\
\text { KM representative }(1.5 \mathrm{hrs})\end{array}$ \\
\hline $\begin{array}{l}\text { K: Australasia based service provider with around } 500 \text { nationally distributed staff. The KM } \\
\text { program had been in place for } 6 \text { years focusing on the implementation and management of KM } \\
\text { tools (document management system, organizational taxonomy, intranet). }\end{array}$ & $\begin{array}{l}\text { Services Provider, } \\
500, \\
\text { Functional structure, } \\
\text { Codification approach }\end{array}$ & $\begin{array}{l}\text { KM leader }(1 \mathrm{hr}) \text {, } \\
\text { KM governance group } \\
\text { representative }(0.5 \mathrm{hr})\end{array}$ \\
\hline $\begin{array}{l}\text { L: Europe based service provider with more than 50,000 internationally distributed staff. The KM } \\
\text { program had been initiated } 4 \text { years ago focusing on individual in-house consulting projects } \\
\text { (targeted collaboration platform, development of debriefing methodology). }\end{array}$ & $\begin{array}{l}\text { Services Provider, } \\
80000, \\
\text { Product structure, } \\
\text { Comprehensive approach }\end{array}$ & $\begin{array}{l}\text { KM leader }(1.5 \mathrm{hrs}) \\
\text { KM leader }(1.5 \mathrm{hrs}) \\
\text { KM leader }(2.5 \mathrm{hrs}) \\
\text { KM staff }(2.5 \mathrm{hrs})\end{array}$ \\
\hline
\end{tabular}


